\title{
BACTERIA BASED SELF-HEALING CONCRETE :A REVIEW
}

\section{${ }^{*}$ Arej K. Mahmod ${ }^{1}$}

\author{
Lubna A. Al-Jabbar ${ }^{1}$
}

\section{Mohammed M. Salman²}

1) Environmental Engineering Department, College of Engineering, Mustansiriyah University, Baghdad, Iraq

2) Civil Engineering Department, College of Engineering, Mustansiriyah University, Baghdad, Iraq

\begin{abstract}
Concrete is one of the most commonly used building materials, and which is prone to cracking. The service life of concrete is significantly reduced due to these cracks. Replacement are High costs and difficulties in avoiding the cracks, various methods are in place to prevent crack formation such as filling in the gaps. It has been demonstrated current treatment methods of concrete are Chemical and polymer applications which they are a source of health and environmental issues, and they are only getting worse successful under some situations. As a result, environmentally sustainable treatment methods will be required in the near future. The potential for long-term, rapid, and active crack repair distinguishes the microbial self-healing method, which is also environmentally friendly. in addition, microbial selfhealing Thanks to the effectiveness of this procedure, which out performs most treatment methods. Concrete compatibility and effective bonding capability assemblages. This paper gives an overview of the various microbial methods for producing calcium carbonate ( $\mathrm{CaCO} 3)$. Future challenges in microbial crack treatment are discussed, as well as recommendations for future research areas.
\end{abstract}

Keywords: Concrete, Crack, Self-healing, Bacteria, Biomineralization, Calcium carbonat

\section{Introduction}

One of the most widely used structural materials is concrete which used in a wide range of applications. It's been commonly used in the design of structures, dams, and storage facilities. Tanks, seaports, highways, bridges, tunnels and other structures are all examples of infrastructures. A combination of aggregates (coarse and fine), water, and cement form a mixture that forms the concrete. Cement is the most important part of concrete that holds aggregates together and bridges the space between fine and coarse particles. High Compressive power, availability, reliability, and compatibility that have to be considered. Lowcost, easy behavior with reinforcement bars preparation, as well as the ability to cast in ideal shapes and sizes for many people, concrete is the material of choice due to its various sizes.

Despite its benefits, concrete has a high proclivity for cracking, allowing harmful to penetrating the structure with chemicals Cracks are one of the most common causes of concrete deterioration and loss of durability. Cracks can appear in both the plastic and hardened states. As a result of the concrete's rapid loss of water, Plastic settlement, shrinkage, and formwork movement all happen. During the plastic molding process, the surface results in the creation of cracks. Weathering, drying shrinkage, and thermal shock are all examples of this. Chemical reaction, stress, design and detailing errors cracks are caused by constant overload and external load hardened state of formation $[43,76$,

*Corresponding Author: arej.karem@gmail.com 
2, 53]. Furthermore, concrete structures tensile strength and ductility are low. The lower tensile strength is a problem that needs to be addressed. Concrete is normally reinforced with embedded steel rods for strength and ductility. Steel bars the use of reinforcement bars has a positive impact. On limiting crack width by regulating plastic shrinkage; they cannot, however, avoid the development of cracks. Although cracks may not jeopardize concrete strength in the short term, they can pose a significant threat to the longevity of the structure in the long term $[51,81,36][16$, $66,53]$. In several countries around the world, a significant budget is set aside each year for the reconstruction of existing cementitious structures $[13,30]$. Early detection and prevention of crack formation is critica in general, pores and cracks in concrete are treated there are two types of treatments: passive and active. Treatments that are not involved can only treat minor cracks on the floor, while active both interior and exterior cracks can be filled with these techniques. Passive treatments can improve the toughness of concrete while also preventing aggressive materials from penetrating it External coatings, such as application, can be used to do this. Polymers and chemical mixtures when it comes to passive therapies, since cracks have been discovered, sealants can either be injected or applied. Alternatively, it can be sprayed through the holes [85, 53]. Waxes, polyurethane epoxy resins, chlorinated rubbers, siloxane, and acrylics are common chemical materials used in these sealers. While passive treatments may be used in a variety of situations, they are not appropriate for everyone. Established concrete structures have a number of drawbacks. Which makes it difficult to use them. The following are some of the shortcomings in the chemical sealants which have a low weather tolerance, low heat resistance, Moisture sensitivity, unreliability, weak concrete bonding, corrosion susceptibility, and different thermal expansion coefficients and delamination with age between sealants and concrete [19,21,22,81]. Active recovery methods (self-healing techniques) can work independently in a variety of situations and crack positions. They're also capable to activate immediately when a cracks forms shape, and crack. Three main strategies for establishing a self-healing mechanism in concrete are as follows: (i) autogenous healing (ii) polymeric encapsulation material (iii) calcium development by microorganisms carbon dioxide,[92]. Autogenous healing is the natural process of restoring concrete cracks that occurs in the presence of moisture or water. Autogenous healing hydrates unhydrated cement particles or carbonates dissolved calcium hydroxide to fill cracks, [59,26]. Calcium hydroxide is formed when calcium oxide is hydrated, and It has the ability to react with atmospheric carbon dioxide.. As eq. $\{1,2\}$ show that these reactions result in calcium carbonate production [35]. Calcium carbonate is one of the most useful building materials because of its nature's abundance and compatibility with cementitious materials. And a variety of fillers to fill in the voids, porosities, and cracks Concrete has cracks:

$$
\begin{aligned}
& \mathrm{CaO}+\mathrm{H}_{2} \mathrm{O} \rightarrow \mathrm{Ca}(\mathrm{OH})_{2} \\
& \mathrm{Ca}(\mathrm{OH})_{2}+\mathrm{CO}_{2} \rightarrow \mathrm{CaCO}_{3}+\mathrm{H}_{2} \mathrm{O}
\end{aligned}
$$

The presence of water or humidity in the natural atmosphere, the amount of unhydrated cement, and the composition of the concrete matrix all play a role in autogenous healing's effectiveness, [80, 87, 89]. Furthermore, only cracks with a diameter of [0.1-0.3] $\mathrm{mm}$ can be filled using Autogenous healing. [18, 60, 4, 57]. Reducing the water to cement ratio $(\mathrm{w} / \mathrm{c})$ is a realistic way to enhance autogenous healing. However, rising the cement component to lower the $(\mathrm{w} / \mathrm{c})$ ratio has a negative impact on shrinkage and workability, and it necessitates further cement 
production. Another form of active treatment is the encapsulation of polymeric materials. By converting a curing agent into foam, this process may aid in the filling of cracks. There is moisture present while chemicals released from incorporated hollow fibers inside concrete may help to fill cracks, [24]. In certain situations, these materials do not act like concrete compositions, and in some cases, they require existing structures to be extended. Furthermore, capsules that can easily be mixed with concrete and survive in a concrete matrix are needed for this technique. Alternative novel active treatment approaches are in demand due to the limitations of conventional procedures. Biotechnological methods have recently attracted the attention of researchers. As a possible solution to the issues that come with active and passive treatments, it has received a lot of coverage. Biomineralization produces calcium carbonate, which is used in the biological healing process. Implementation of successful this novel treatment approach would extend the lifetime of concrete structures while also lowering structural replacement and cement production costs.

\section{Biomineralization}

The formation of minerals by living organisms is known as biomineralization, and it is a regular phenomenon in nature [76]. The biologically mediated mineralization method can be used to achieve biomineralization. Biologically induced mineralization normally takes place in, As a result of uncontrolled microbial metabolic activity in the environment, an open environment has resulted [61]. When the metabolic products produced by bacteria interact with their surroundings, biominerals are formed. Figure (1) depicts the structure of bacteria as well as a schematic diagram of calcium carbonate $\mathrm{CaCo}_{3}$ formation. Mineral precipitation occurs when positively charged ions successfully bind to negatively charged microbial cell walls.
Biologically mediated mineralization occurs most often in anaerobic environments or at the oxic-anoxic boundary. The powerful bonding ability and widespread processing of minerals through biomineralization has piqued interest in calcium carbonate precipitation. Compatibility with concrete compositions.

\section{Calcium Carbonate Precipitation}

Microorganisms, specifically bacteria, are known to be capable of producing a broad variety of minerals, including phosphates, silicates, sulphides, and phosphates carbonates [31]. Calcium is a mineral that is found in In the presence of a calcium source, carbonate may be precipitated through a biologically induced mineralization process. Extracellularly through two metabolic pathways namely autotrophic and heterotrophic.

\subsection{Autotrophic Pathway}

In the presence of $\mathrm{CO} 2$, microbes convert carbon $\mathrm{CO} 2$ to carbonate in one of three ways: (i) nonmethylotrophic methanogenesis

(by methanogenic archaea) (ii) oxygenic photosynthesis (by Cyanobacteria), (iii) anoxygenic photosynthesis (by anoxygenic archaea) are all examples of photosynthesis (by purple bacteria) [15]. $\mathrm{CO}_{2}$ and $\mathrm{H}_{2}$ are converted to methane in the non-methylotrophic methanogenesis pathway (Eq. 3). As a result, as shown in (Eq. 4) Produced Calcium carbonate precipitation will then occur. As shown in Eq. 5. The presence of calcium ions in marine sediments, this pathway is more common.

$\mathrm{CO}+4 \mathrm{H}_{2} \rightarrow 2 \mathrm{H}_{2} \mathrm{O}+\mathrm{CH}_{4}$

$\mathrm{CH}_{4}+\mathrm{SO}_{4}{ }^{2-} \rightarrow \mathrm{HCO}_{3-}+\mathrm{H}_{2} \mathrm{O}+\mathrm{HS}^{-}$

$\mathrm{Ca}^{2-}+2 \mathrm{HCO}_{3-} \leftrightarrow \mathrm{CaCO}_{3}+\mathrm{H}_{2} \mathrm{O}+\mathrm{CO}_{2}$

In the presence of calcium ions, photosynthesis is also an autotrophic mechanism for producing calcium carbonate. In oxygenic photosynthesis, 
water serves as an electron donor, as shown in (Eq. 6). In oxygenic photosynthesis, water serves as an electron donor.

In the redox reaction, however, hydrogen sulphide (H2S) acts as an electron donor in anoxygenic photosynthesis. As a result, no oxygen is produced (Eq. 7) [52]. Carbonate is generated when carbon dioxide is removed from bicarbonate solutions during microbial photosynthesis [48]. In the presence of calcium ions, this phenomenon causes a localized rise in $\mathrm{pH}$ and, eventually, precipitation calcium carbonate [34].

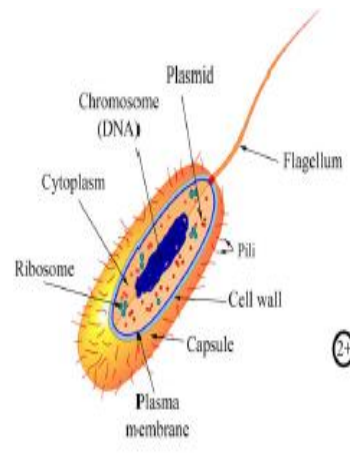

(a)

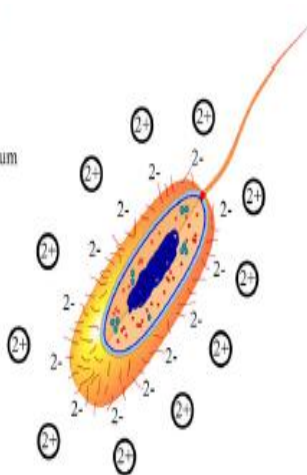

(b)

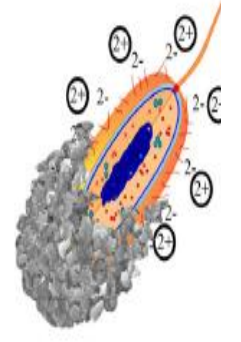

(c)
Figure 1. a) Bacterial structure. b) Negatively charged cell wall with positive charged ions. c) Biomineralization via ion binding to the cell wall

Eqs. 6-9 provide a description for the production of calcium carbonate, photosynthesis chemical reactions are used.

$$
\mathrm{H}_{2} \mathrm{O}+\mathrm{CO}_{2} \rightarrow^{\text {Oxygenic Photosynthesis }}\left(\mathrm{CH}_{2} \mathrm{O}\right)+\mathrm{O}_{2}
$$

$\mathrm{CO}_{2}+2 \mathrm{H}_{2} \mathrm{~S}+\mathrm{H}_{2} \mathrm{O} \rightarrow$ Anoxygenic Photosynthesis $\left(\mathrm{CH}_{2} \mathrm{O}\right)+2 \mathrm{~S}+2 \mathrm{H} 2 \mathrm{O}$

$2 \mathrm{HCO}_{3}{ }^{-} \leftrightarrow \mathrm{CO}_{2}+\mathrm{CO}_{3}{ }^{2-}+\mathrm{H}_{2} \mathrm{O}$

$\mathrm{CO}_{3}{ }^{2-}+\mathrm{H}_{2} \mathrm{O} \leftrightarrow \mathrm{HCO}_{3}{ }^{-}+\mathrm{OH}^{-}$

This is an example of only carbon dioxide and light-exposed areas of concrete structures can use the photosynthesis pathway.

\subsection{Heterotrophic Pathway}

As a result of their expansion in a variety of natural environments, microbial communities may precipitate crystals. Arthrobacter, bacillus and Rhodococcus species grow heterotrophically on organic acid salts such as (acetate, lactate, and other) carbonate minerals are formed as a result of these reactions. These bacteria get their energy from organic compound such bacteria can produce a variety of crystals depending on the salts and carbon sources in the medium magnesium carbonate and calcium carbonate are two types of carbonates (Eqs. 10-12) list the ions. [42].

$$
\begin{aligned}
& \mathrm{CH} 3 \mathrm{COO}^{-}+2 \mathrm{O}_{2} \rightarrow \text { Heterotrophic bacteria } 2 \mathrm{CO}_{2}+\mathrm{H}_{2} \mathrm{O} \\
& +\mathrm{OH} \\
& 2 \mathrm{CO} 2+\mathrm{OH}^{-} \rightarrow \mathrm{CO}_{2}+\mathrm{HCO}_{3}^{-} \\
& 2 \mathrm{HCO}_{3}^{-}+\mathrm{CO}_{2} \rightarrow \mathrm{CaCO}_{3}+\mathrm{CO}_{2}+\mathrm{H}_{2} \mathrm{O}
\end{aligned}
$$

Organic acid precipitation of calcium carbonate use would be observed in a variety of Caves (walls, ceilings, and speleothems), marines, and soils are examples of substrate ecosystems. Soils and lakes are two examples. In the presence of calcite, Calcium carbonate could be produced by heterotrophic bacterial populations (Arthrobacter and Rhodococcus) isolated from cave stalactites. $[63,33]$. Furthermore, the function of It has been thoroughly examined Arthrobacter and Rhodococcus species isolated from polar habitats in calcium carbonate crystal precipitation using calcium citrate and calcium acetate as carbon sources. [12, 62]. Calcium carbonate can be precipitated by Bacillus and Arthrobacter species according to another conceptual study. Under the influence of an alkaline carbonate medium in the following section, the viability of these microbes in a concrete matrix will be addressed. Proteins and extracellular polymeric substances (EPS) have a big influence on calcium carbonate's shape and mineralogy formed (as nucleation sites). Other mechanisms for processing calcium 
carbonate include the sulphur cycle and the nitrogen cycle. Dissimilatory sulphate reduction follows the sulphur cycle. When a calcium supply, organic matter, and sulphate are present in the media, calcium carbonate is formed. The reaction shifts towards the precipitation of calcium carbonate as the $\mathrm{pH}$ rises due to the degasification of hydrogen sulphide [15]. Eqs. [13-16] demonstrate how sulphatereducing bacteria produce calcium carbonate by reducing calcium sulphate $\left(\mathrm{CaSO}_{4}\right)$ to calcium sulphide (CaS).[27]

$$
\begin{aligned}
& \mathrm{CaSO}_{4}+2\left(\mathrm{CH}_{2} \mathrm{O}\right) \rightarrow \mathrm{CaS}+2 \mathrm{CO}_{2}+2 \mathrm{H}_{2} \mathrm{O} \\
& \mathrm{CaS}+2 \mathrm{H} 2 \mathrm{O} \rightarrow \mathrm{Ca}(\mathrm{OH})_{2}+\mathrm{H}_{2} \mathrm{~S} \\
& \mathrm{CO}_{2}+\mathrm{H}_{2} \mathrm{O} \rightarrow \mathrm{H}_{2} \mathrm{CO}_{3} \\
& \mathrm{Ca}(\mathrm{OH})_{2}+\mathrm{H}_{2} \mathrm{CO}_{3} \rightarrow \mathrm{CaCO}_{3}+2 \mathrm{H}_{2} \mathrm{O}
\end{aligned}
$$

Through the nitrogen cycle, carbonate or bicarbonate can be generated through three main pathways:(i ) dissimilatory nitrate reduction (ii) ammonification amino acid synthesis, ( iii) urea or uric acid degradation (ureolysis), $[14,55]$. Calcium carbonate is precipitated as a result of the nitrogen cycle when there is enough calcium ion in the medium [15] The calcium carbonate production in concrete as a result of the nitrogen cycle will be discussed in the following sections.

\section{Precipitation of Calcium Carbonate in Concrete Matrix}

In the presence of calcium, bacteria through metabolic processes, bacteria like Bacillus sphaericus and Bacillus pasteurii can create biominerals (Table 1) [85]. These urease-positive microbes are involved in the nitrogen cycle and can create calcium.

\begin{tabular}{|c|c|c|c|c|}
\hline Mechanism of precipitation & Mictorganism & Nutrient & $\begin{array}{l}\text { Enbednent } \\
\text { in concrete }\end{array}$ & Referenes \\
\hline \multirow{4}{*}{$\begin{array}{l}\text { Bocleriel madabolic conversikn } \\
\text { of arganic acid }\end{array}$} & 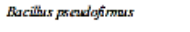 & 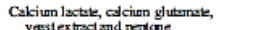 & Direct & bonkas and Schtergen (2009) \\
\hline & 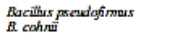 & 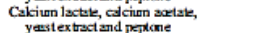 & Direct & kankas el al (2010) \\
\hline & & Cakiun lactle and yeas extrat & Inroxotilized & Siemso Beltran el al (2014) \\
\hline & 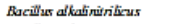 & Cakiun lactok and yeas extrat & Innotilized & Wiktor and borkens (2011) \\
\hline \multirow[t]{16}{*}{ Urahlyyis } & Bacï̈ur -p.phacrizas & Uree, cakium nitrate and yest ex trad & Irrmotilized & Warg etal.(2014h) \\
\hline & Bocil̈us -phaerizar & Urea and cakium chlonide & & Achal et al(2013) \\
\hline & Bacil̈ur sphaerizar & Uren, cakium ritrate and yesid extrad & Irrmotilized & Wang etzal.(2012a) \\
\hline & Bacillus sphaerizus & Ura and cakium chleride & Direct & Achalet al (2011) \\
\hline & Bucillus sphaerizus & Urae, cakium nitrate and yeas ex trad & Inrmotilived & Warg elal. (2010) \\
\hline & Bucïlus spherizars & $\begin{array}{l}\text { Ures, cakiun chldride, cakiun nitsele } \\
\text { and yeas extrat }\end{array}$ & Irrmotilized & Ven Tittelboum el al (2010) \\
\hline & 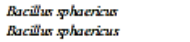 & 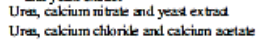 & $\begin{array}{l}\text { Irrmotilitived } \\
-\end{array}$ & $\begin{array}{l}\text { Wsig etzal.(2014c) } \\
\text { De Muynck etzal. (2008z) }\end{array}$ \\
\hline & 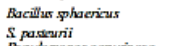 & $\begin{array}{l}\text { Uras, cakium nitrate sid yest extrad } \\
\text { Urea and cakium chkmide }\end{array}$ & $\begin{array}{l}\text { Irmotilized } \\
\text { Dreect }\end{array}$ & $\begin{array}{l}\text { Waig el ts. (2012b) } \\
\text { Ranschander et al (2001) }\end{array}$ \\
\hline & 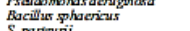 & Urew and caktium scetete & Direct & Kimet al (2013) \\
\hline & 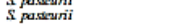 & Ural and cakium chknide & Innostilived & Bang et al. (2001) \\
\hline & $S_{\text {pastanii }}$ & Ures, cakium nitrate sid cakium cilcride & - & Qismet al (2010b) \\
\hline & $S_{\text {pasterii }}$ & Urat and cakium nitrate & & Chunxieng et al (20019) \\
\hline & $S_{\text {passevii }}$ & Ura and cakcium chiknide & Irrnostitived & Bergy et al. (2010) \\
\hline & $\begin{array}{l}S_{\text {pastenoii }} \\
\text { Bacillus cervos }\end{array}$ & Ures, nutrient troth sid cakinn chlonde & Dind & Malewweranet al. (2014) \\
\hline & Bacillus amybliqugugciens & Ures, cakium scette yest extrat & - & Lee $(2003)$ \\
\hline & 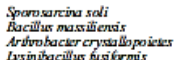 & Uraw and caktiun chlonide & Dreect & Pasik el al. (20110) \\
\hline Dexultílicabion & 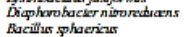 & 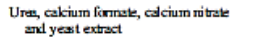 & Irrmotilived & Erscen et al (20115s) \\
\hline
\end{tabular}

Table. 1 A summary of the microorganisms and nutrients used in the production of calcium carbonate in concrete matrix.

Carbonate through urea hydrolysis [7, 38, 91]. The basic reactions that cause calcium carbonate precipitation are depicted. In Eqs $(17,18)$ [23].

$\mathrm{Ca}^{2+}+\mathrm{CO}_{3}^{2-} \leftrightarrow \mathrm{CaCO}_{3}$
$\mathrm{Ca}^{2+}+2 \mathrm{HCO}_{3}^{-} \leftrightarrow \mathrm{CaCO} 3+\mathrm{CO} 2+\mathrm{H} 2 \mathrm{O}$

Carbonate concentration and $\mathrm{pH}$ rise as a result of microbial metabolic activities [74, 81, 53]. Carbon dioxide is converted to carbonate more easily when the $\mathrm{pH}$ is raised [87]. In nature) that acts as a barrier, preventing corrosive chemicals from entering cracks [23, 50].

Urease activity produces 1 mol carbamic acid $(\mathrm{NH} 2 \mathrm{COOH})$ and $1 \mathrm{~mol}$ ammonia $(\mathrm{NH} 3)$ from urea hydrolysis in the presence of bacteria (Eq. 19). Carbamic acid hydrolysis yields $1 \mathrm{~mol}$ carbonic acid (H2CO3) and 1 mol additional ammonium, as stated in (Eq. 20).

$\mathrm{CO}(\mathrm{NH} 2)_{2}+\mathrm{H}_{2} \mathrm{O} \rightarrow \mathrm{NH}_{2} \mathrm{COOH}+\mathrm{NH}_{3}$

$\mathrm{NH}_{2} \mathrm{COOH}+\mathrm{H} 2 \mathrm{O} \rightarrow \mathrm{NH} 3+\mathrm{H} 2 \mathrm{CO} 3$

Carbonate $(\mathrm{CO} 3)$ is formed by the interaction of hydroxide ion with carbonic acid (which is already formed by the reaction of water and ammonia with carbonic acid, according to Eqs. $(21,22)$ [11]. As Positively charged calcium ions 
can bind to the negatively charged bacterial cell, as shown in (Eq. 23).

$2 \mathrm{NH} 3+2 \mathrm{H} 2 \mathrm{O} \rightarrow 2 \mathrm{NH}^{+} 4+2 \mathrm{OH}^{-}$

$2 \mathrm{OH}^{-}+\mathrm{H} 2 \mathrm{CO}_{3} \rightarrow \mathrm{CO}^{2-} 3+2 \mathrm{H}_{2} \mathrm{O}$

$\mathrm{Ca}^{2+}+$ Cell $\rightarrow$ Cell $-\mathrm{Ca}^{2+}$

Cell $-\mathrm{Ca}^{2+}+\mathrm{CO}^{2-}{ }_{3} \rightarrow$ Cell $-\mathrm{CaCO} 3$

To complete the last process, calcium ion can be created either by internal sources located in the cement structure or by adding chemicals such as calciumchloride (Eq. 24). Externally, calcium nitrate or calcium lactate [75]. Calcium chloride as a calcium source can result in chloride ion attack and, as a result, reinforcement bar degradation. As a result, calcium is applied It is suggested that you use nitrate or calcium lactate. (Figure 2) shows the formation by B. sphaericus and B. subtilis on calcium carbonate crystals. While this technique has proven to be effective, there are still certain faults that must be addressed. Are formed. Nitrogen oxide is released into the atmosphere as a result of ureolytic action. It is estimated that $10 \mathrm{~g} / \mathrm{L}$ is needed to remediate $1 \mathrm{~m}^{2}$ of concrete. Urea, which yields (4.7grams) of nitrogen this sum is approximately one-third of the nitrogen produced by each individual on an everyday [20]. As a result, an optimization is needed to prevent excessive ammonium emissions, it is desirable to find the appropriate amount of urea. The metabolic conversion of organic molecule (organic acid salt) to calcium carbonate was proposed to alleviate the drawbacks of ammonium ion formation via the ureolysis route. $[38,91,70,36]$.In this process, aerobic oxidation of organic acids produces carbon dioxide, which results in carbonate production in environment which is alkaline, When a calcium supply is present as a cation, calcium carbonate is formed [40] .Eq- 25 shows the metabolic conversion of calcium lactate to calcium carbonate in the presence of oxygen[38].
$\mathrm{CaC}_{6} \mathrm{H}_{10} \mathrm{O}_{6}+6 \mathrm{O}_{2} \rightarrow$ Metabolic conversion $\mathrm{CaCO}_{3}+5 \mathrm{CO}_{2}+5 \mathrm{H}_{2} \mathrm{O}(25)$

The reaction between the calcium oxide in the concrete matrix and the generated water and carbon dioxide from (Eq. 25). is autogenous healing $[2,3,80]$. While big calcium source concentrations are needed for calcite production [10] this can lead to salt accumulation in the concrete matrix. As a result, the calcium source concentration must be optimized to minimize costs, avoid salt formation, and achieve optimal calcium carbonate. Producing this method's advantages include compatibility with concrete composition, high calcium carbonate output, and reinforcement bar safety. Dissimilatory nitrate reduction is another method for mineral production. Bacteria that decompose nitrogen the most important feature of this method is that it can be used in anaerobic zones. Denitrobacillus, Thiobacillus, and other facultative anaerobes are among the microorganisms involved in the denitrification method. Micrococcus, Alcaligenes, Pseudomonas, Spirillum, Achromobacter, and Alcaligenes [40]. Water, Carbon dioxide, and nitrogen are released as a result of organic compound denitrification (Eq. 26) according to Eq. 27. Calcium carbonate is precipitated as a result between the final reaction of calcium source and carbonate.(Eq, 28).

Organic compound $+\mathrm{a} \mathrm{NO}_{3}^{-}+\mathrm{b} \mathrm{H}^{+} \rightarrow{ }^{\text {Denitrification }} \mathrm{c} \mathrm{CO} 2+$

$\mathrm{H} 2 \mathrm{O}+\mathrm{e} \mathrm{N} 2$

$\mathrm{CO}_{2}+2 \mathrm{OH}_{-} \rightarrow \mathrm{CO}^{2-}{ }_{3}+\mathrm{H}_{2} \mathrm{O}$

$\mathrm{Ca}^{2+}+\mathrm{CO}_{3}^{2-} \rightarrow \mathrm{CaCO}_{3}$

The production of calcium carbonate in concrete through the denitrification process is not well understood and requires further study. This mechanism is superior to the ureolytic approach it can also be used in agricultural soil sector. The hydrolysis of urea takes only a few minutes. Calcium carbonate precipitation via the ureolysis pathway is therefore the favored technique. Among the biomineralization mechanisms for 
calcium carbonate. This is the quickest method [20]. Because calcium carbonate biomineralization is sluggish, nutrients that can accelerate the process are in high demand. Furthermore, low-risk candidates should be chosen bacteria with a high capacity to precipitate calcium carbonate, as well as growth rate, and enzyme activity are favored. Bacterial over growth, on the other hand, may result in the formation having an uncontrollable biofilm on the surface and an uneven surface [32]. In order to avoid bacterial overgrowth and maximize precipitation, the optimal amount of nutrients and inoculum size must be optimized. A description of microorganisms.

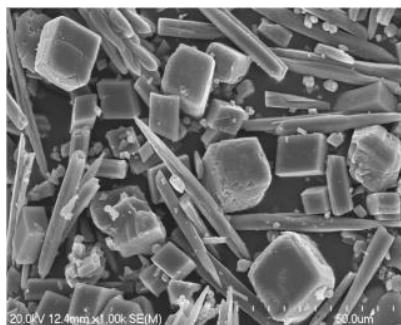

(a)

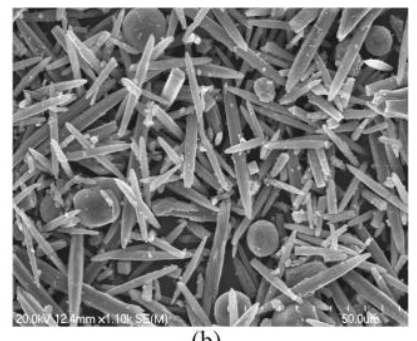

(b)
Figure 2. a) SEM micrographs of B. sphaericus calcite precipitation. b) SEM micrographs showing B. subtilis calcite precipitation.

\section{Embedment of Microorganism in Concrete Matrix}

Healing agents (bacteria and nutrients) can be injected directly into the concrete matrix via the vascular network or mixed in during the mixing process. The vascular approach was influenced by the bone structure in humans. There are two pieces of a bone. The compact cortical bone is on the outside, and the spongy trabecular bone is on the inside. As shown in "Fig. 3a", the vascular technique uses distributed vascular networks to deliver healing agents from outside the system. During the concrete preparation, it became embedded in the matrix. Owing to the pressure gradient between the agent source and the crack locations, the healing agent travels through the vessel when cracks emerge [24]. Proposed a selfhealing mechanism in which single or multiple hollow vascular fibers were used to connect the internal and exterior concrete sections. Another investigation was conducted [68]. Vascular networks were simulated using cylindrical concrete with porous center and compact outer sections, respectively. The porous center disperses the weight. It is possible to trigger the healing agent via the concrete matrix as soon as a crack occurs in the structure's outer part. Owing to many flaws, the network of veins approach it appears to be impractical. When the amount of a healing agent that has been released exceeds the crack potential, problems of appearance arise. Second, uniform vessel distribution across the structure will be difficult. Finally, there's incorporation the presence of Concrete with a circulatory system can diminish the connection between concrete compositions. Resulting in structural delamination. As shown in Fig. 3b.bacillus species, for example, are alkaliphilic bacteria that can withstand the harsh concrete environment, making them for bio self-healing, this is the most appealing species. These thick membrane spore-forming bacteria, according to studies, can live for hundreds of years without nutrition [69]. Furthermore, dormant endospores can withstand changes in the atmosphere, chemicals, ultraviolet radiation, and mechanical stresses [73, 36, 80].

Direct introduction of microorganisms into building materials like concrete, on the other hand, has a significant impact on microbial metabolic activity. Dryness and a high pH (>11) even bacteria are susceptible to death due to the state of the concrete $[85,36]$. 


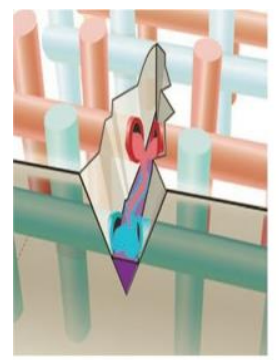

(a)

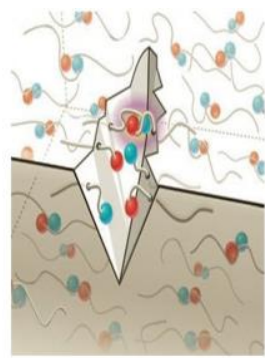

(b)

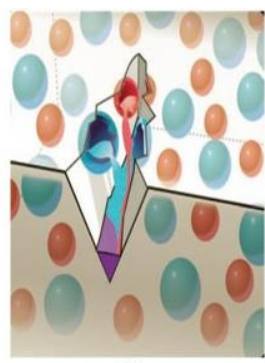

(c)
Figure 3. There are three basic types of self-healing: a) vascular, b) mixing with other ingredients, c) encapsulation [9].

Table 2. Effect of microbial agent on compressive strength,

\begin{tabular}{|c|c|c|c|c|c|}
\hline \multirow{3}{*}{ Microorganism } & \multirow{2}{*}{\multicolumn{2}{|c|}{$\begin{array}{l}\text { Effect on } \\
\text { compressive } \\
\text { strength }\end{array}$}} & & & \\
\hline & & & \multicolumn{2}{|c|}{ Effect on durability } & \multirow[t]{2}{*}{ References } \\
\hline & Effect & $\begin{array}{l}\text { Time } \\
\text { (day) }\end{array}$ & $\begin{array}{l}\text { Perme } \\
\text { ability }\end{array}$ & $\begin{array}{c}\text { Water } \\
\text { absorption }\end{array}$ & \\
\hline \multirow{10}{*}{$\begin{array}{c}\text { Bacillus } \\
\text { sphaericus }\end{array}$} & $\mathrm{N}$ & 28 & $\mathrm{P}$ & - & \multirow{3}{*}{$\begin{array}{l}\text { Wang et al. } \\
(2014 \mathrm{c})\end{array}$} \\
\hline & $\mathrm{N}$ & 90 & & & \\
\hline & $\mathrm{P}$ & 3 & _ & $P$ & \\
\hline & $\mathrm{P}$ & 7 & & & \multirow{3}{*}{$\begin{array}{l}\text { Achal et al. } \\
\text { (2011) }\end{array}$} \\
\hline & $\mathrm{P}$ & 21 & & & \\
\hline & $\overline{\mathrm{P}}$ & $\overline{7}$ & $\overline{\mathrm{P}}$ & . & \\
\hline & $\mathrm{P}$ & 28 & & & \multirow{3}{*}{$\begin{array}{l}\text { Wang et al. } \\
(2012 \mathrm{~b}) \\
\text { Achal et al. } \\
\quad(2013)\end{array}$} \\
\hline & _- & _- & $\mathrm{P}$ & _ & \\
\hline & - & - & $\mathrm{P}$ & - & \\
\hline & & & & & $\begin{array}{l}\text { Wang et al. } \\
(2014 \mathrm{~b}\end{array}$ \\
\hline \multirow[t]{4}{*}{ S. pasteurii } & $\mathrm{P}$ & 7 & - & - & \multirow{3}{*}{$\begin{array}{l}\text { Bang et al. } \\
\text { (2010) }\end{array}$} \\
\hline & $\mathrm{P}$ & & \multirow{3}{*}{ - } & & \\
\hline & \multirow[t]{2}{*}{$\mathrm{P}$} & \multirow[t]{2}{*}{28} & & \multirow[t]{2}{*}{$P$} & \\
\hline & & & & & $\begin{array}{c}\text { Chahal et al. } \\
\text { (2012) }\end{array}$ \\
\hline \multirow[t]{3}{*}{ Bacillus cohnii } & $\mathrm{P}$ & 7 & \multirow[t]{3}{*}{ - } & \multirow[t]{3}{*}{-} & \multirow{3}{*}{$\begin{array}{l}\text { Sierra-Beltran } \\
\text { et al. (2014) }\end{array}$} \\
\hline & $\mathrm{P}$ & 28 & & & \\
\hline & $\mathrm{P}$ & 56 & & & \\
\hline \multirow{3}{*}{$\begin{array}{c}\text { Bacillus } \\
\text { pseudofirmus }\end{array}$} & $\mathrm{N}$ & & \multirow[t]{3}{*}{ - } & \multirow[t]{3}{*}{ - } & \multirow{3}{*}{$\begin{array}{l}\text { Jonkers et al. } \\
\quad(2010)\end{array}$} \\
\hline & $\mathrm{N}$ & 7 & & & \\
\hline & $\mathrm{N}$ & 28 & & & \\
\hline \multirow{2}{*}{$\begin{array}{c}\text { Diaphorobacter } \\
\text { nitroreducens }\end{array}$} & $\mathrm{N}$ & 7 & \multirow[t]{2}{*}{ - } & \multirow[t]{2}{*}{-} & \multirow{2}{*}{$\begin{array}{c}\text { Erşan et al. } \\
\text { (2015a) }\end{array}$} \\
\hline & $\mathrm{N}$ & 28 & & & \\
\hline
\end{tabular}

These findings suggest that bacteria cells could survive in concrete structures for up to 4 months (135 days). Immobilized spore forming bacteria must be incorporated into bacteria to enable them survive in severe conditions for longer periods of time [47]. Some articles have focused on Encapsulation of bacteria or the use of protective materials like diatomaceous earth, hydrogel, and porous expanded clay particles are used to provide defense [91, 84]. The encapsulation of a curing The incorporation of the agent "Fig. 3c" into tubular or ball-shaped capsules helps bacteria's long-term survival during the concrete preparation phase, microcapsules resist mechanical forces. When the capsule ruptures as a result of the fracture, the healing process begins. The major challenges of encapsulation include the empty area left following capsule activation, as well as the preparation and mixing of capsules with aggregate technique recently, researchers looked into the impact of embedding a curing crack treatment agent in tubular glasses [84]. Alkaline solutions are harmful to silicate materials such as glass. The glass tube (vessel) wall dissolves because cement-based composites are extremely alkaline as a result, glass corrosion develops. Capsule resistance can be improved during mixing by reducing the radius of the capsule or increasing the thickness of the capsule wall. However, as the radius in terms of thickness ratio decreases, the capsules may be unable to activate as a crack occurs. Expanding the amount of capsules incorporated resulting in a vast region of surface this can reduce the cohesiveness of the binders, reducing the workability of the concrete $[80,82]$. Microcapsules have been found to cause the formation of larger pores when used to fill pores. Incorporating microcapsules into samples resulted in lower mechanical properties [87]. As a result, encapsulation efficiency is determined solely by capsule size, within the concrete matrix, characteristics and distribution are important. As a result, immobilization to address encapsulation challenges, bacteria can be encapsulated in hydrogel, expanded clay, silica gel, granular activated carbon, zeolite, and metakaolin [29]. Under extreme conditions, the The viability of bacteria implanted in silica gels has been tested observed, and immobilization of bacteria in hydrogels has been investigated [73, 86]. It was discovered that a swollen hydrogel would provide additional water to improve 
calcium carbonate precipitation's ability to fill the void cavity. Cracks with a diameter of up to $0.5 \mathrm{~mm}$ Bacteria were immobilized in polyurethane and silica gel [85]. The use of silica gels to prevent bacteria and algae from losing their enzymatic activity has been discovered [72].

\section{Performance of Bioconcrete}

Concrete's compressive strength and toughness are the most important attributes. It is essential to assess the impact of biomineralization on these attributes. Cracks, pore size, and their relationship concrete properties and, as a result, the service life of concrete buildings are negatively affected by distribution. Concrete's durability by decreasing absorption, permeability, and diffusion, performance can be improved. Which are liquid and gas transportation into concrete has a number of main mechanisms. [53]. several studies have looked at the impact of bio-based healing agents on concrete permeability and water absorption. Table 2 shows the relationship between permeability and water. The presence of biobased agents have decreased the absorption of concrete structures [84]. Studies have investigated the effect of using It was previously reported that the permeability of immobilized B. sphaericus cells calcium carbonate precipitation was specimens with bacteria immobilized in polyurethane is six times decreases than that of specimens without bacteria Furthermore, the ability of immobilized B. sphaericus in diatomaceous earth to absorb water has been reported. The results indicated that the water absorption in specimens with immobilized bacteria was $50 \%$ of specimens without bacteria $[85,2]$. It was discovered that using B. sphaericus made the concrete watertight. According to the permeation test over the period of 168 hours, the amount of water in the control specimens the existence of freshly as a result of bacterial metabolism, calcium carbonate was formed. May explain the observed phenomenon. According to reports, the application compressive strength decreases by 15 to $34 \%$ when encapsulated B. sphaericus is used in mortar [86]. While the At a cell concentration of the bio-based chemical had a beneficial effect on compressive strength 5 $\mathrm{x} 10^{6}$ cells $/ \mathrm{mm}^{3}$, the compressive strength of the mortar was reduced higher cell concentration $\left(10^{8}\right.$ cells $\left./ \mathrm{mm}^{3}\right)$ [6]. Sporosarcina pasteurii was tested effect on the For 7 and 28 days, the compressive strength of mortar specimens was measured. The compressive strength of the mortar specimen was found to have the highest concentration can be increased by $24 \%$ when S. pasteurii is immobilized on porous glass beads. Moreover, as the cell concentration was increased from $6.1 \times 10^{7}$ to $3.1 \times 10^{9}$ cells $/ \mathrm{cm}^{3}$, compressive strength improved. [29] Reported on the compressive strength of protective materials containing immobilized ureolytic and denitrifying bacteria. Their research found that using B. sphaericus in concrete reduced compressive strength by 63 and $60 \%$ in 7 and 28 days, respectively. Although the use of a denitrifying bacterium (Diaphorobacter nitroreducens) reduced compressive strength for 7 and 28 days. The brittleness of the calcium carbonate produced could explain these contradictory results. In addition, various culture media and nutrients are used these differences may be due to a variety of factors, including Environmental factors. The biomineralization process may also plug inside the concrete matrix, there are porosities and voids, in addition to surface cracks. As a result, using microorganisms that can produce smaller bio-minerals may help to reconcile the conflicting compressive strength results.

\section{Conclusion and Prospective}

Bio Self-Healing is application that pays tribute to itself over current treatment methods due to 
their susceptibility to effective binding, It is compatible with concrete formulations and sustainability. It has the ability to fill in deep micro cracks while also preventing cracking. As a result, inspection and maintenance labor costs would be reduced $[38,86]$. Furthermore, because cement production is reduced, carbon dioxide emissions are decreased $[21,19,8]$. Reduction structure porosity, creating the concrete is watertight, and the precipitated calcium carbonate and the cement mix are compatible the cement other advantages of this method include concrete compositions and favorable thermal expansion. Construction materials that have undergone bio self-healing treatment are safer, more durable, and more cost-effective. Consequently, comparison to traditional treatment approaches, mixing a method is promising as it combines a healing agent with during the casting process, cement and other ingredients are used. There are a number of significant issues that must be addressed for early future industrial application. Despite recent advances Existing findings will be used to develop procedures for bio-based self-healing concrete continue to be plagued by a deficiency in numerical simulation to reduce investigational costs and time [78, 77]. Furthermore, the Possibility of a healing agent being used during more research is needed into the mixing, as well as the activity of bacteria in hardened concrete throughout time. Bond coherence between the filler and the crack edge is another desired factor to evaluate in order to avoid fresh crack formation. Aside from the concrete's durability as a result of the biobased healing strategy, the expense of manufacturing bio-concrete is another issue. There is a need for more research into microorganisms, nutrients, and their interactions, reduction of associated costs. Certainly, in the early future Contractors will be encouraged to use bioconcretes as the preferred material as a result of ways to increase the efficiency of bio self-healing while lowering costs.

\section{Conflict of Interest}

The authors declare that there are no conflicts of interest regarding the publication of this manuscript.

\section{References}

1. Achal V, Mukerjee A, Sudhakara Reddy M (2013). "Biogenic treatment improves the durability and remediates the cracks of concrete structures". Constr Build Mater 48: $1-5$

2. Achal V, Mukherjee A, Sudhakara Reddy M (2011). "Microbial concrete: way to enhance the durability of building structures". J Mater Civil Eng 23:730-734

3. Achal V, Pan X (2011). "Characterization of urease and carbonic anhydrase producing bacteria and their role in calcite precipitation”. Curr Microbiol 62:894-902

4. Ahn TH, Kishi T (2009). "The effect of geomaterials on the autogenous healing behavior of cracked concrete". ICCRRR II. Cape Town, South Africa pp 125-126

5. Bang SS, Galinat JK, Ramakrishnan V (2001). "Calcite precipitation induced by polyurethane-immobilized Bacillus pasteurii”. Enzyme Microb Tech 28:404409

6. Bang SS, Lippert JJ, Yerra U, Mulukutla S, Ramakrishnan V (2010). "Microbial calcite, a bio-based smart nanomaterial in concrete remediation". Int J Smart Nano Mater 1:28-39

7. Barton LL, Northup DE (2011). "Microbial ecology. Wiley- Blackwell Belie ND, Muynck W (2008) Crack repair in concrete using biodeposition. ICCRRR II. Cape Town, South Africa 291-292

8. Berenjian A, Chan N, Malmiri HJ (2012). "Volatile organic compounds removal methods: a review". Am J Biochem Biotechnol 8:220-229

9. Blaiszik BJ, Kramer SLB, Olugebefola SC, Moore JS, Sottos NR, White SR (2010). 
"Self-healing polymers and composites". Ann Rev Matern Res 40:179-211

10. Burbank MB, Weaver TJ, Green TL, Williams B, Crawford RL (2011). "Precipitation of calcite by indigenous microorganisms to strengthen liquefiable soils". Geomicrobiol J 28:301-312

11. Burne RA, Chen YYM (2000). "Bacterial ureases in infectious diseases". Microbes Infect 2:533-542

12. Cacchio P, Ercole C, Cappuccio G, Lepidi A (2003). "Calcium carbonate precipitation by bacterial strains isolated from a limestone cave and from a loamy soil". Geomicrobiol J 20:85-98

13. Cailleux E, Pollet V (2009). "Investigations on the development of self healing properties in protective coatings for concrete and repair mortars". 2nd International Conference on Self-Healing Materials, Chicago, USA

14. Castainer S,Metayer-Levrel GL, Perthuisot $\mathrm{J}$ (2000). "Bacterial roles in the precipitation of carbonate minerals. In: Riding RE, Awramik SM (eds) Microbial sediments". Springer, Berlin Heidelberg, pp. 32-39

15. Castainer S, Metayer-Levrel GL, Perthuisot JP (1999). "Ca-carbonates precipitation and limestone genesis-the microbiogeologist point of view". Sediment Geol 126:9-23

16. Chahal N, Siddique R, Rajor A (2012). "Influence of bacteria on the compressive strength, water absorption and rapid chloride permeability of fly ash concrete". Constr Build Mater 28:351-356

17. Chunxiang Q, Jianyun W, Ruixing W, Liang C (2009). "Corrosion protection of cementbased building materials by surface deposition of CaCO3 by Bacillus pasteurii”. Mater Sci Eng 29:1273-1280

18. Clear CA (1985)." Effects of autogenous healing upon the leakage of water through cracks in concrete". Cement and Concrete Association, USA

19. De Muynck W, Cox K, Belie ND, Verstraete W (2008b). "Bacterial carbonate precipitation as an alternative surface treatment for concrete”. Constr Build Mater 22:875-885

20. De Muynck W, De Belie N, Verstraete W (2010). "Microbial carbonate precipitation in construction materials: a review". Ecol Eng 36:118- 136

21. De Muynck W, Debrouwer D, De Belie N, Verstraete W (2008a). "Bacterial carbonate precipitation improves the durability of cementitious materials". Cement Concrete Res 38:1005-1014

22. Dhami N, Mukherjee A, Reddy MS (2012). "Biofilm and microbial applications in biomineralized concrete". In: Seto J (ed) Advanced Topics in Biomineralization, InTech, pp 137-164

23. Dick J, DeWindtW, De Graef B, Saveyn H, Van DerMeeren P, De Belie N, VerstraeteW (2006). "Bio-deposition of a calcium carbonate layer on degraded limestone by Bacillus species". Biodegradation 17:357367

24. Dry C. (1994). "Matrix cracking repair and filling using active and passive modes for smart timed release of chemicals from fibers into cement matrices". Smart Mater Struct 3:118 123

25. Ebrahiminezhad A, Najafipour S, Kouhpayeh A, Berenjian A, Rasoul- Amini S, Ghasemi Y (2014). "Facile fabrication of uniform hollow silica microspheres using a novel biological template". Colloid Surface B 118:249-253

26. Edvardsen C (1999). "Water permeability and autogenous healing of cracks in concrete”. ACI Mater J 96:448-454

27. Ehrlich HL (1995) .Geomicrobiology Marcel Dekker Inc, New York

28. Erşan YÇ, Belie ND, Boon N (2015b). "Microbially induced $\mathrm{CaCO} 3$ precipitation through denitrification: an optimization study in minimal nutrient environment". Biochem Eng J 101:108-118

29. Erşan YÇ, Da Silva FB, Boon N, Verstraete $\mathrm{W}$, De Belie N (2015a). "Screening of bacteria and concrete compatible protection materials”. Constr Build Mater 88:196-203

30. Federal Highway Administration (FHWA) (2001) Corrosion cost and preventive 
strategies in the United States. NACE International

31. Fortin D, Ferris FG, Beveridge TJ (1997) Surface-mediated mineral development by bacteria. Rev Mineral 35:161-180

32. Ghaz-Jahanian MA, Khodaparastan F, Berenjian A, Jafarizadeh-Malmiri H (2013) Influence of small RNAs on biofilm formation process in bacteria. Mol Biotechnol 55:288-297

33. Groth I, Schumann P, Laiz L, SanchezMoral S, Cañveras JC, Saiz- Jimenez C (2001)." Geomicrobiological study of the Grotta dei Cervi, Porto Badisco, Italy". Geomicrobiol J 18:241-258

34. Hammes F, VerstraeteW (2002). "Key roles of $\mathrm{pH}$ and calcium metabolismin microbial carbonate precipitation". Rev Environ Sci Biotechnol 1:3-7

35. Hearn N (1998). "Self-sealing, autogenous healing and continued hydration: what is the difference?" Mater Struct 31:563-567

36. Jonkers HM (2011). "Bacteria-based selfhealing concrete". Heron 56:5-16

37. Jonkers HM, Schlangen E (2009). "A two component bacteria-based selfhealing concrete”. Concrete Repair, Rehabilitation and Retrofitting II, ICCRRR Cape Town South Africa

38. Jonkers HM, Thijssen A, Muyzer G, Copuroglu O, Schlangen E (2010) ." Application of bacteria as self-healing agent for the development of sustainable concrete”. Ecol Eng 36:230-235

39. Kar SZ, Berenjian A (2013). " Soil formation by ecological factors: critical review". Am J Agric Biol Sci 8:114-116

40. Karatas I (2008). "Microbiological improvement of the physical properties of soils". Dissertation Arizona State University

41. Kim HK, Park SJ, Han JI, Lee HK (2013). "Microbially mediated calcium carbonate precipitation on normal and lightweight concrete". Constr Build Mater 38:10731082

42. Knorre H, Krumbein KE (2000). "Bacterial calcification, in Microbial sediments,
Riding RE, Awramik SM”. Springer, Berlin, pp. 25-31

43. Le Métayer-Levrel G, Castanier S, Orial G, Loubière JF, Perthuisot JP (1999). "Applications of bacterial carbonatogenesis to the protection and regeneration of limestones in buildings and historic patrimony". Sediment Geol 126:25-34

44. Lee YN (2003). "Calcite production by Bacillus amyloliquefaciens CMBO1”. J Microbiol 41:345-348

45. Li VC, Herbert E (2012). "Robust selfhealing concrete for sustainable infrastructure". J Adv Concr Technol 10:207-218

46. Maheswaran S, Dasuru SS, Rama Chandra Murthy A, Bhuvaneshwari B, Ramesh Kumar V, Palani GS, Iyer NR, Krishnamoorthy S, Sandhya S (2014). "Strength improvement studies using new type wild strain Bacillus cereus on cement mortar”. Curr Sci India 106:50-57

47. Malmiri HJ, JahanianMAG, Berenjian A (2012). "Potential applications of chitosan nanoparticles as novel support in enzyme immobilization". Am J Biochem Biotechnol 8:203-219

48. Mann S (2001). "Biomineralization: principles and concepts in bioinorganic materials chemistry “. Oxford University Press, New York

49. Munn CB (2004). "Marine microbiology: ecology and applications". Bios Scientific Publisher, London

50. MuynckW, Belie N, VerstraeteW(2007). "Improvement of concrete durability with the aid of bacteria". Proceedings of the first international conference on self healing materials. Noordwijk aan zee, The Netherlands

51. Neville AM, Brooks JJ (2010). "Concrete technology". Pearson, United Kingdom

52. Okafor N (2011). "Environmental microbiology of aquatic and waste systems". Springer, Netherlands

53. Pacheco-Torgal F, Labrincha JA (2013). "Biotech cementitious materials: some aspects of an innovative approach for 
concrete with enhanced durability”. Constr Build Mater 40:1136-1141

54. Park SJ, Park YM, ChunWY, KimWJ, Ghim SY (2010). “Calcite-forming bacteria for compressive strength improvement in mortar". J Microbiol Biotechn 20:782-788

55. Perito B, MastromeiG(2011). "Molecular basis of bacterial calcium carbonate precipitation, in molecular biomineralization". W.E.G, Müller, Editor

56. Qian C,Wang R, Cheng L, Wang J (2010a). "Theory of microbial carbonate precipitation and its application in restoration of cement-based materials defects". Chinese J Chem 28:847-857

57. Qian SZ, Zhou J, Schlangen E (2010b). "Influence of curing condition and precracking time on the self-healing behavior of engineered cementitious composites". Cement Concrete Composites 32:686-693

58. Ramachandran SK, Ramakrishnan V, Bang SS (2001). "Remediation of concrete using micro-organisms". ACI Mater J 98:39

59. Ramm W, Biscoping M (1998). "Autogenous healing and reinforcement corrosion of water-penetrated separation cracks in reinforced concrete". Nucl Eng Des 179:191-200

60. Reinhardt HW, Jooss M (2003). "Permeability and self-healing of cracked concrete as a function of temperature and crack width". Cement Concrete Res 33:981985

61. Rivadeneyra MA, Delgado R, Del Moral A, Ferrer MR, Ramos- Cormenzana A (1994). "Precipitation of calcium carbonate by Vibrio spp. from an inland saltern”. FEMS Microbiol Ecol 13: 197-204

62. RonholmJ, Schumann D, SapersHM, Izawa M, Applin D, Berg B, Mann P, Vali $\mathrm{H}$, Flemming RL, Cloutis EA, Whyte LG (2014). "A mineralogical characterization of biogenic calcium carbonates precipitated by heterotrophic bacteria isolated from cryophilic polar regions". Geobiology 12:542-556
63. Rusznyák A, Akob DM, Nietzsche S, Eusterhues K, Totsche KU, Neu TR, Frosch T, Popp J, Keiner R, Geletneky J, Katzschmann L,

64. Schulze E, Küsel K (2012). "Calcite biomineralization by bacterial isolates from the recently discovered pristine karstic herrenberg cave". Appl Environ Microb 78:1157-1167

65. Şahmaran M, Keskin SB, Ozerkan G, Yaman IO (2008) Self-healing of mechanically-loaded self consolidating concretes with high volumes of fly ash. Cement Concrete. Composites 30:872-879

66. Samani AK, Attard MM (2012). "A stress-strain model for uniaxial and confined concrete under compression". Eng Struct 41:335-349

67. Samani AK, Attard MM (2014).” Lateral strain model for concrete under compression”. ACI Struct J 111:441-451

68. Sangadji S, Schlangen E (2013). "Mimicking bone healing process to self repair concrete structure novel approach using porous network concrete". Procedia Engineering 54:315-326

69. Schlegel H (1993) General microbiology. University Press, Cambridge

70. Sierra-Beltran MG, Jonkers HM, Schlangen E (2014). "Characterization of sustainable bio-based mortar for concrete repair". Constr Build Mater 67:344-352

71. Silva FB, Boon N, De Belie N, VerstraeteW(2015). "Industrial application of biological self-healing concrete: challenges and economical feasibility". J Commerc Biotechnol 21:31-38

72. Soltmann U, Böttcher H (2008). "Utilization of sol-gel ceramics for the immobilization of living microorganisms". $\mathrm{J}$ Sol-Gel Sci Techn 48: 66-72

73. Soltmann U, Raff J, Selenska-Pobell S, Matys S, Pompe W, Böttcher H (2003). "Biosorption of heavy metals by sol-gel immobilized Bacillus sphaericus cells, spores and S-layers". J Sol-Gel Sci Techn 26:1209- 1212 
74. Stocks-Fischer S, Galinat JK, Bang SS (1999). "Microbiological precipitation of CaCO3". Soil Biol Biochem 31:1563-1571

75. Stuckrath C, Serpell R, Valenzuela LM, Lopez M (2014). "Quantification of chemical and biological calcium carbonate precipitation: performance of self-healing in reinforced mortar containing chemical admixtures". Cement Concrete Composites 50:10-15

76. Tebo BM, Johnson HA, McCarthy JK, Templeton AS (2005) Geomicrobiology of manganese(II) oxidation. Trends Microbiol $13: 421-428$

77. Vaghari H, Eskandari M, Sobhani V, Berenjian A, Song Y, Jafarizadeh- Malmiri $\mathrm{H}$ (2015). "Process intensification for production and recovery of biological products". Am J Biochem Biotechnol $11: 37-43$

78. Van Breugel K (2007). Is there a market for self-healing cement based materials? The first international conference on selfhealing materials. Noordwijk aan zee, The Netherlands

79. Van Paassen LA, Daza CM, Staal M, Sorokin DY, van der Zon W, van Loosdrecht MCM (2010) Potential soil reinforcement by biological denitrification. Ecol Eng 36:168-175

80. Van Tittelboom K, De Belie N (2013). "Self-healing in cementitious materials-a review". Materials 6:2182-2217

81. Van Tittelboom K, De Belie N, De MuynckW, VerstraeteW(2010) Use of bacteria to repair cracks in concrete. Cement Concrete Res 40:157-166

82. Van Tittelboom K, De Belie N, Van Loo D, Jacobs P (2011). "Self-healing efficiency of cementitious materials containing tubular capsules filled with healing agent". Cement Concrete Composites 33:497-505

83. Wang J, Dewanckele J, Cnudde V, Van Vlierberghe S, Verstraete W, De Belie N (2014a). "X-ray computed tomography proof of bacterialbased self-healing in concrete". Cement Concrete Composites 53: 289-304

84. Wang J, Van Tittelboom K, De Belie N, Verstraete W (2012a). "Use of silica gel or polyurethane immobilized bacteria for selfhealing concrete". Constr Build Mater 26:532-540

85. Wang JY, De Belie N, Verstraete W (2012b). "Diatomaceous earth as a protective vehicle for bacteria applied for self-healing concrete". J Ind Microbiol Biot 39:567-577

86. Wang JY, Snoeck D, Van Vlierberghe S, Verstraete W, De Belie N (2014b). "Application of hydrogel encapsulated carbonate precipitating bacteria for approaching a realistic self-healing in concrete". Constr Build Mater 68:110-119

87. Wang JY, Soens H, Verstraete W, De Belie N (2014c). "Self-healing concrete by use of microencapsulated bacterial spores". Cement Concrete Res 56:139-152

88. Wang JY, Van Tittelboom K, De Belie N, Verstraete W (2010). "Potential of applying bacteria to heal cracks in concrete". 2nd International Conference on Sustainable Construction Materials and Technologies

89. Wang X, Xing F, ZhangM, Han N, Qian $\mathrm{Z}$ (2013) Experimental study on cementitious composites embedded with organic microcapsules. Materials 6:40644081

90. Warscheid T, Braams J (2000). "Biodeterioration of stone: a review". Int Biodeter Biodegr 46:343-368

91. Wiktor V, Jonkers HM (2011)." Quantification of crack-healing in novel bacteria-based self-healing concrete". Cement Concrete Composites 33:763-770

92. Wu M, Johannesson B, Geiker M (2012). “A review: self-healing in cementitious materials and engineered cementitious composite as a self-healing material". Constr Build Mater 28:571-583 